\title{
Produksi Fruktosa dari Tongkol Jagung Sebagai Gula Rendah Kalori
}

\author{
Mahyati $^{1, a}$, dan Octovianus SR Pasanda ${ }^{1, b}$ \\ 1 Jurusan Teknik Kimia Politeknik Negeri Ujung Pandang \\ Jl. Perintis Kemerdekaan KM.10 Makassar, Kode Pos 90245 Indonesia \\ a Email : mahyatikimia@poliupg.ac.id \\ bEmail: o.pasanda@yahoo.com
}

\begin{abstract}
Corn cobs as waste organic agricultural having content $\pm 45 \%$ cellulose. Cellulose is a biopolymer that can be converted into glucose. Glucose can be produced by A.niger and T.ressei through fermentation process. Glucose in generate can be developed to become fructose syrup through a process isomerisasi with enzymes glucoisomerase prodused by Streptomyces $S p$. This research using corn cobs yellow as a source of cellulose for the production of fructose. The purpose of this research is to find concentration fructose syrup obtained from fermentation process. Convertion cellulose be done in enzimatis use A.niger and T.ressei through the fermentation process by adding Saccharomyces cerevisiae. The process continues with isomerization use Streptomyces $S p$. The process isomerization done with variations time is $1,2,3$, and 4 hour and variation $\mathrm{pH}$ 6,7, and 8. Analysis concentration glucose and fructose of fermentation product performed with GCMS. The highest result obtained was fermentation 1 hour at $\mathrm{pH} 6$ with glukoce $6,7 \%$ and fructose $16,22 \%$.
\end{abstract}

Keywords--Corn Cobs, Streptomyces Sp dan Fructose

\begin{abstract}
Abstrak--Tongkol jagung sebagai limbah organik pertanian yang memiliki kandungan selulosa $\pm 45 \%$. Selulosa merupakan biopolimer yang dapat dikonversi menjadi glukosa. Glukosa dapat dihasilkan oleh A.niger dan T.ressei melalui proses fermentasi. Glukosa yang dihasilkan dapat dikembangkan menjadi sirup fruktosa melalui proses isomerisasi menggunakan enzim glukoisomerase yang dihasilkan dari bakteri Streptomyces Sp. Penelitian ini menggunakan tongkol jagung kuning (Zea mays var indurate) sebagai sumber selulosa untuk memproduksi fruktosa. Tujuan dari penelitian ini adalah untuk mengetahui konsentrasi sirup fruktosa yang diperoleh dari proses fermentasi. Konversi selulosa dilakukan secara enzimatis menggunakan A.niger dan T.ressei melalui proses fermentasi dengan penambahan Saccharomyces cerevisiae. Proses dilanjutkan dengan isomerisasi menggunakan Streptomyces Sp. Proses isomerisasi dilakukan dengan variasi waktu $1,2,3$, dan 4 jam dan variasi pH 6,7, dan 8. Analisis kadar glukosa dan fruktosa dari produk fermentasi dilakukan dengan alat GCMS. Hasil tertinggi yang diperoleh adalah fermentasi 1 jam pada pH 6 dengan kadar glukosa $6,7 \%$ kadar fruktosa $16,22 \%$.
\end{abstract}

Kata Kunci: Tongkol jagung, Streptomyces $S p$ dan fruktosa

\section{Pendahuluan}

Produksi jagung produksi jagung di Sulawesi selatan mencapai 1,49 juta ton [1] dan berpotensi menghasilkan limbah tongkol jagung yang mencapai $30 \%$ dari berat total jagung [2]. Pada hal tongkol jagung mengandung selulosa, hemiselulosa, dan lignin. Dari ketiga komponen tersebut, selulosa merupakan komponen yang dapat di konversi glukosa. Peluang untuk memproduksi gula (glukosa) dari tongkol jagung dapat juga menjadi solusi karena kebutuhan pemanis di Indonesia yang cukup tinggi. Pada tahun 2014 kebutuhan gula nasional mencapai 5.700 juta ton (KEMENPERIN). Produksi glukosa dari tongkol jagung dapat dilakukan secara fisika, kimia dan biologi (enzimatik). Proses konversi secara enzimatik menggunakan enzim selulase yang dapat dihasilkan oleh A. niger dan $T$. reesei pada hari ke 7 dengan $\mathrm{pH}$ awal 4 mencapai 13,88\% [3].

Glukosa yang dihasilkan dari fermentasi dapat dikembangkan menjadi sirup fruktosa (High Fructose Syrup) melalui proses isomerisasi. Pada tahun 1970an peneliti pangan mempelajari cara mengubah glukosa menjadi fruktosa melalui proses isomerisasi menggunakan enzim glukosa isomerase. Enzim glukosa isomerase yang digunakan dalam proses ini dapat diperoleh dari Streptomyces $S p$. Enzim glukosa isomerase ini mengubah D-glukosa menjadi D-fruktosa. Enzim glukosa isomerase untuk menghasilkan sirup fruktosa dilakukan dengan mengekstrak sel-sel mikroba karena enzim ini bersifat intraseluler [4].

Streptomyces $S p$ dapat memproduksi enzim glukoisomerase untuk mengkonversi glukosa dari hasil sakarifikasi menjadi fruktosa yang lebih mudah dimetabolisme oleh tubuh sehingga sangat aman untuk 
pasien diabetes, obesitas dan penderita jantung. Sirup fruktosa memiliki tingkat kemanisan 2,5 kali lebih besar dibanding sirup glukosa. Disamping itu sirup fruktosa memiliki indeks glikemik lebih rendah $(32+2)$ dibanding glukosa $(138+4)$. Oleh sebab itu sirup fruktosa bisa untuk pemanis penderita diabetes [5].

\section{II.Metode Penelitian}

Sampel dibersihkan, dipotong kecil kira-kira $5 \mathrm{~cm}$ dan dikeringkan. Sebelum proses isomerisasi dan dilakukan analisis kadar glukosa dan fruktosa menggunakan alat GCMS. Selanjutnya difermentasi menggunakan (A.niger, T.reseei, dan Streptomyces Sp.)

\section{A. Proses hidrolisis dan fermentasi dengan metode SSF:} Pembuatan media starter

- 1.95 gram PDA dan 1 gram bacto agar ke dalam 100 $\mathrm{ml}$ aquades pada gelas kimia $250 \mathrm{ml}$.

- Membuat media ekstrak taoge ( untuk Tricoderma reesei dan Aspergilus niger) dengan mendidihkan 1 gram Toge , 1.5 gram bacto agar dan 2 gram glukosa dalam $100 \mathrm{ml}$ aquades pada gelas kimia $250 \mathrm{ml}$ selama 15 menit.

- Membuat media NB ( untuk Streptomyces Sp.) dengan melarutkan 0.4 gram NB dan 1 gram bacto agar dalam $100 \mathrm{ml}$ aquades pada gelas kimia $250 \mathrm{ml}$.

\section{B. Pembuatan media produksi}

- Membuat larutan nutrisi Aspergilus niger dengan melarutkan glukosa 12.5 gram, $\left(\mathrm{NH}_{4}\right)_{2} \mathrm{SO}_{4} 0.25$ gram, tongkol jagung 1 gram dan $\mathrm{KH}_{2} \mathrm{PO}_{4} 0.2$ gram kedalam $100 \mathrm{ml}$ aquades pada Erlenmeyer $250 \mathrm{ml}$.

- Membuat larutan nutrisi Tricoderma reesei dengan melarutkan glukosa 12.5 gram, $\left(\mathrm{NH}_{4}\right) \mathrm{SO}_{4} 0.25$ gram, tongkol jagung 1 gram, $\mathrm{MgSO}_{4} .7 \mathrm{H}_{2} \mathrm{O} 0.05$ gram, $\mathrm{FeSO}_{4} \cdot 6 \mathrm{H}_{2} \mathrm{O} \quad 0.0001$ gram dan $\mathrm{KH}_{2} \mathrm{PO}_{4} 0.2$ gram kedalam $100 \mathrm{ml}$ akuades pada erlenmeyer $250 \mathrm{ml}$.

- Hasil fermentasi menggunakan analisis GCMS.

Variabel yang digunakan parameter analisis yaitu waktu fermentasi (1, 2, 3, dan 4 jam). Variabel ke dua yang digunakan yaitu $\mathrm{pH}(6,7$ dan 8$)$ dengan waktu fermentasi 1 jam.

\section{Hasil dan Pembahasan}

Proses lignifikasi pada tongkol jagung terjadi kehilangan lignin sebesar 8\% yaitu dari kandungan lignin awal sebanyak $20 \%$ menurun hingga $12 \%$ setelah 2 kali perlakuan pendahuluan yaitu lignifikasi menggunakan $\mathrm{KOH} \mathrm{4 \%} \mathrm{[6].}$
Setelah pengurangan kadar lignin dilakukan proses hidrolisis dengan menggunakan A.niger dan T. ressei untuk mengkonversi selulosa menjadi glukosa dengan pemutusan ikatan selulosa tongkol jagung yang telah terlignifikasi oleh enzim. Proses sakarifikasi dilakukan dengan menggunakan campuran A. niger, T. resei dan Saccaromices cereviciae pada $\mathrm{pH} 4,5$ pada suhu ruang.

Selain glukosa pada proses ini telah menghasilkan fruktosa sebesar 11,1\% tetapi masih besar kadar 15,4\% yang dapat digunakan untuk proses fermentasi menggunakan enzimisomerase dari mikroba.

Tabel 1. Kadar glukosa dan fruktosa setelah fermentasi tahap 1 (sakarifikasi)

\begin{tabular}{|c|c|c|c|}
\hline No. & Proses & $\begin{array}{c}\text { Kadar glukosa } \\
(\mathbf{\%})\end{array}$ & $\begin{array}{c}\text { Kadar fruktosa } \\
\mathbf{( \% )}\end{array}$ \\
\hline 1 & Sakarifikasi 1 & 1.5 & 1,9 \\
\hline 2 & Sakarifikasi 2 & 2,0 & 1,7 \\
\hline 3 & Sakarifikasi 2 & 0.9 & 1.9 \\
\hline 4 & Sakarifikasi 2 & 15,4 & 11,1 \\
\hline
\end{tabular}

Selanjutnya glukosa sebesar $15,4 \%$ yang diperoleh dari fermentasi pada tahap awal dilakukan fermentasi lanjutan dengan menggunakan Streptomyces Sp. yang mampu menghasilkan enzim gluko isomerase.

Proses hidrolisis subtrat dioptimasi dengan variasi waktu pada pH 7 (netral) untuk mendapatkan waktu optimal. Hasil yang diperoleh ditunjukkan pada Gambar 1.

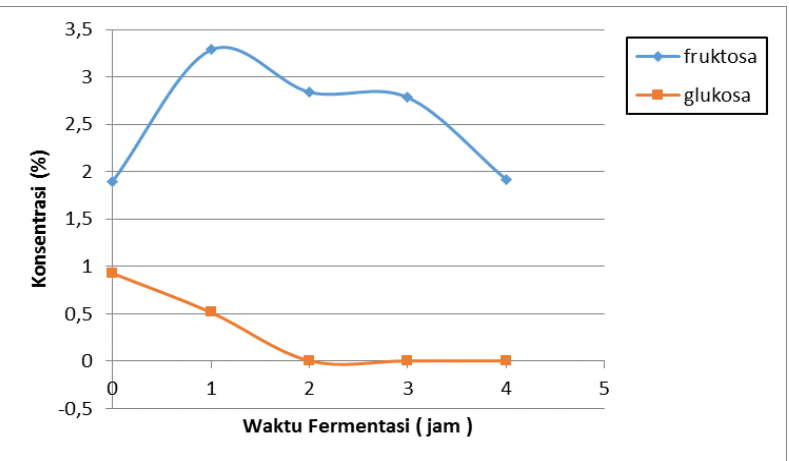

Gambar 1. Kadar fruktosa terhadap pengaruh waktu terhadap konsentrasi fruktosa optimal yang dihasilkan.

Ketika mencapai waktu fermentasi mencapai 1 jam, produksi glukoisomerase semakin banyak sehingga perubahan glukosa menjadi fruktosa semakin tinggi sehingga proses isomerisasi dapat berjalan optimal. Setelah 1 jam, produksi fruktosa hasil isomerisasi semakin menurun. Pada saat fermentasi 2 hingga 4 jam, konsentrasi fruktosa kembali menurun mikroba sudah mulai berkurang karena ketersediaan nutrisi pada medium sudah mulai berkurang sehingga proses pembelahan dan aktivitas fermentasi sel terhambat yang 
akibatnya hasil samping fermentasi seperti $\mathrm{CO}_{2}$, sedikit asam-asam volatile, alkohol,dll.

Penurunan kadar fruktosa juga diikuti dengan penurunan konsentrasi glukosa, hal ini dapat disebabkan oleh kinerja enzim glukoisomerase yang merubah glukosa menjadi fruktosa menurun atau menuju pada fase kematian / non-aktif.

Derajat Keasaman merupakan faktor yang juga penting untuk optimasi kerja mikroorganisme. Oleh karena itu, dilakukan optimasi $\mathrm{pH}$ subtrak isomerisasi untuk mengetahui pada $\mathrm{pH}$ berapa enzim glukoisomerase dapat bekerja optimal pada subtrat sirup gula hasil sakarifikasi berbahan tongkol jagung.

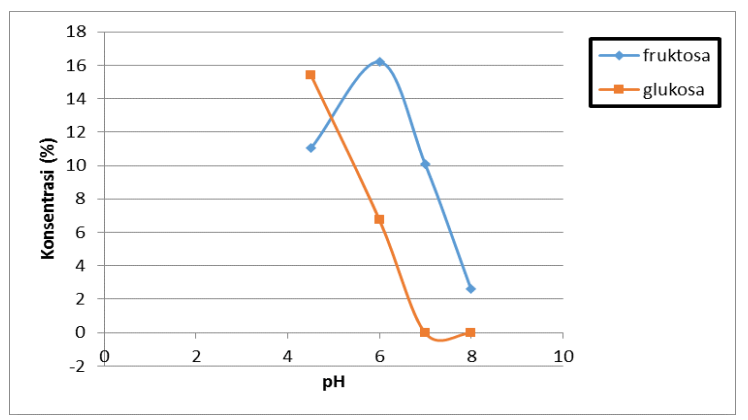

Gambar 2. Pengaruh $\mathrm{pH}$ terhadap konsentrasi fruktosa yang dihasilkan

Streptomyces mampu tumbuh optimum pada temperatur $25{ }^{\circ} \mathrm{C}$ dan $\mathrm{pH} 6,5-8,0$ Berdasarkan $\mathrm{pH}$ tersebut maka dilakukan fermentasi pada $\mathrm{pH} \mathrm{6,7,8}$ sehingga diperoleh kinerja enzim optimal pada $\mathrm{pH} 6$ yaitu dengan konsentrasi fruktosa $16.2 \%$, mengalami kenaikan 4\% dari konsentrasi awal. Aktivitas enzim mulai menurun pada $\mathrm{pH} 7$ yaitu dari konsentrasi awal $11 \%$ menjadi $10 \%$ bahkan pada $\mathrm{pH} 8$ terjadi penurunan drastis yaitu menurun $9 \%$ dari konsentrasi awal.

Tabel 2. Perbandingan kadar glukosa dan fruktosa hasil fermentasi

\begin{tabular}{|l|c|}
\hline \multicolumn{1}{|c|}{ Perlakuan } & $\begin{array}{c}\text { Perbandingan Kandungan } \\
\text { (Glukosa : Fruktosa) }\end{array}$ \\
\hline Sebelum isomerisasi & $15: 11$ \\
\hline Setelah isomerisasi & $6: 16$ \\
\hline
\end{tabular}

Rasio perbandingan glukosa dan fruktosa sebelum fermentasi isomerisasi diperoleh 15:11. Proses isomerisasi selama 1 jam pada $\mathrm{pH} 6$ mampu merubah perbandingan glukosa dan fruktosa menjadi $6: 16$. Peningkatan konsentrasi terlihat secara jelas untuk konsentrasi fruktosa sedangkan glukosa mengalami enurunan. Penurunan dapat disebabkan oleh kinerja enzim glukoisomerase. Enzim glukoisomerase bekerja dengan cara mengubah isomer glukosa menjadi fruktosa. Kinerja enzim glukoisomerase ditandai dengan peningkatan konsentrasi fruktosa setelah proses isomerisasi yang diikuti oleh penurunan konsentrasi glukosa.

Sebagian besar glukosa diikuti dengan isomerisasi glukosa dalam sirup jagung fruktosa untuk menghasilkan fruktosa HFCS-42 (42\% fruktosa dan glukosa 58\%) [7].

\section{Kesimpulan}

Kesimpulan dari hasil penelitian sebagai berikut :

1. Fruktosa yang dihasilkan dari proses fermentasi sakarifikasi bahan baku tongkol jagung menggunakan T.ressei, A.niger dan Saccharomyces pada suhu ruang dengan $\mathrm{pH} 4,5$ adalah $11,5 \%(\mathrm{~b} / \mathrm{v})$ dan pada proses isomerisasi dengan kondisi optimum pada $\mathrm{pH} 6$ selama 1 jam fermentasi diperoleh 16,2\% (b/v).

2. Kandungan glukosa dan fruktosa setelah isomerisasi diperoleh perbandingan $6: 16$ dengan kondisi optimum pada $\mathrm{pH} 6$ selama 1 jam fermentasi.

\section{Ucapan Terima Kasih}

Ucapan terima kasih diberikan kepada Bapak Direktur Politeknik Negeri Ujung Pandang yang telah membiayai penelitian melalui dana DIPA Politeknik Negeri Ujung Pandang.

\section{Daftar Pustaka}

[1] BPS,2014, Produksi jagung

[2] Koswara, J. 1991. Budidaya jagung manis (zae mays saccharata) Bahan kursus budidaya jagung manis dan jagung merang. Fakultas Pertanian. IPB, Bogor

[3] Mahyati, 2014, Biokonversi Lignoselulosa dari tongkol jagung (Zea mays.L) menjadi bioetanol sebagai bahan bakar alternative terbarukan,Program pasca sarjana fakultas Matematika dan ilmu pengetahuan alam Universitas Hasanudin,Makassar.

[4] Kusnadi dan Didik Priyando, 2011. Biologi Dasar. Jakarta: Piranti Darma Kalokatama.

[5] Richana, N. 2010. Tepung Jagung Termodifikasi Sebagai Pengganti Terigu. Warta Penelitian dan Pengembangan Vol. 32 (1) $: 6$

[6] Hargreaves, A., Moore, S., Fink, D., Brayman, C., \& White, R. (2003). Succeeding leaders? A study of principal rotation and succession. Toronto, Ontario, Canada: Ontario Principals' Council.

[7] Parker, Kay, Michelle Salas dan Veronica C. Nwosu. 2010. High Fructose Corn Syrup: Production, Uses and Public Health Concerns. USA: Department of Biology, College of Science and Technology, North Carolina Central University. 